\title{
Significance of marine protected areas in central Chile as seeding grounds for the gastropod Concholepas concholepas
}

\author{
Patricio H. Manríquez, Juan Carlos Castilla* \\ Estación Costera de Investigaciones Marinas and Departamento de Ecología, Facultad de Ciencias Biológicas, \\ Pontificia Universidad Católica de Chile, Casilla 114-D, Santiago, Chile
}

\begin{abstract}
The importance of non-harvested areas, marine protected areas, and management and exploitation areas (= harvest-controlled) as seeding areas of Concholepas concholepas (Bruguière, 1789) larvae was quantitatively evaluated at intertidal and subtidal sites at Las Cruces, central Chile. Egg capsules of C. concholepas were sampled along both intertidal and subtidal strip-transects monthly in harvested, harvest-controlled and non-harvested areas from September 1990 to December 1993. Additionally, egg capsules of $C$. concholepas were sampled at subtidal sites in the 3 categories of areas during 1993 and 1994. Spawning activity of C. concholepas was consistently concentrated between February and July in both the intertidal and the subtidal zones. The total area occupied by egg capsules of $C$. concholepas was larger in non-harvested than in harvested areas; moreover, larger capsules were found in non-harvested areas. These differences in total surface occupied by egg capsules and their sizes have an important impact on the estimated number of $C$. concholepas larvae that would be released from harvested and non-harvested areas. We conclude that protected areas may play an important role in the natural replenishment of $C$. concholepas stocks.
\end{abstract}

KEY WORDS: Marine protected areas · Harvested areas · Seeding grounds · Concholepas concholepas $\cdot$ Egg capsule $\cdot$ Larvae $\cdot$ Intertidal $\cdot$ Subtidal $\cdot$ Chile

\section{INTRODUCTION}

No-take marine protected areas (MPAs) and management and exploitation areas (MEAs; Castilla 1994, 1996) represent 2 of the most promising management tools for sustainable exploitation of nearshore marine benthic resources (Castilla 2000). There is a growing literature (Bohnsack 1993, Castilla 1994, Fernández \& Castilla 1997, Castilla \& Fernández 1998, Castilla et al. 1998) on the positive effects of MPAs and MEAs on nearshore resources (population and biomass replenishment, increases in size of individuals and in capture per unit effort) following (1) total closure of nearshore areas (e.g. for crabs); (2) implementation of rotating

*Corresponding author: E-mail: jcastilla@genes.bio.puc.cl harvesting systems (e.g. for sea urchins); and (3) allocation of small-scale fishery rights (Castilla et al. 1998). Nevertheless, there is little quantitative evidence on the role played effects of MPAs and MEAs on larval export. Castilla \& Schmiede (1979) addressed the role of 'buffer' inshore areas (i.e. underfished areas) along the Chilean coastline. They hypothesized that larvae generated there greatly outnumbered those produced in overfished grounds and could be instrumental in restocking populations of valuable benthic invertebrates such as the muricid gastropod Concholepas concholepas (Bruguière, 1789), known in Chile as 'loco'. The assumption was that increases in density and individual size in an underfished population would affect reproductive output.

Our study on the gastropod Concholepas concholepas (Castilla 1982, 1988a) presents data on intertidal 
and subtidal reproduction, laying of egg-capsules, and estimated numbers of larvae liberated to the plankton. We compare results from different categories of exposed rocky shores: (1) the unfished MPA at Las Cruces in central Chile $\left(33^{\circ} 31^{\prime} \mathrm{S}, 71^{\circ} 38^{\prime} \mathrm{W}\right)$, a single non-replicated site, versus adjacent semi-protected and open-access areas; (2) the MEA fishing ground at Caleta El Quisco $\left(33^{\circ} 23^{\prime} \mathrm{S}, 71^{\circ} 42^{\prime} \mathrm{W}\right)$, a single nonreplicated area, versus an adjacent open-access fishing ground at Taulauque $\left(33^{\circ} 25^{\prime} \mathrm{S}, 71^{\circ} 42^{\prime} \mathrm{W}\right)$.

\section{MATERIAL AND METHODS}

The intertidal portion of the study was conducted in central Chile from September 1990 to September 1993 at 3 sites (Fig. 1). The first site was Las Cruces Catholic University Marine Protected Area (MPA) $\left(33^{\circ} 31^{\prime} \mathrm{S}\right.$, $71^{\circ} 38^{\prime} \mathrm{W}$ ) (Fig. 1), a rocky shore approximately $0.8 \mathrm{~km}$ long, with 5 ha subtidal area; it is a unique no-take area that has been protected and closed to the public, thereby excluding rocky-shore food gatherers, divers and small-scale fishers, since 1982 (Castilla 1999). The second site was a semi-protected area, adjacent (south) to the MPA, approximately $1 \mathrm{~km}$ long, with 7 ha subtidal area; it is a fishing ground open to divers, but semirestricted in access by a private owner's fence. The third site was an open-access area adjacent (north) to the MPA, approximately $0.8 \mathrm{~km}$ long and with 4 ha subtidal area, which is a heavily visited by tourists, and open to small-scale fishery divers. The 3 areas display similar ecological and geological characteristics (Oliva

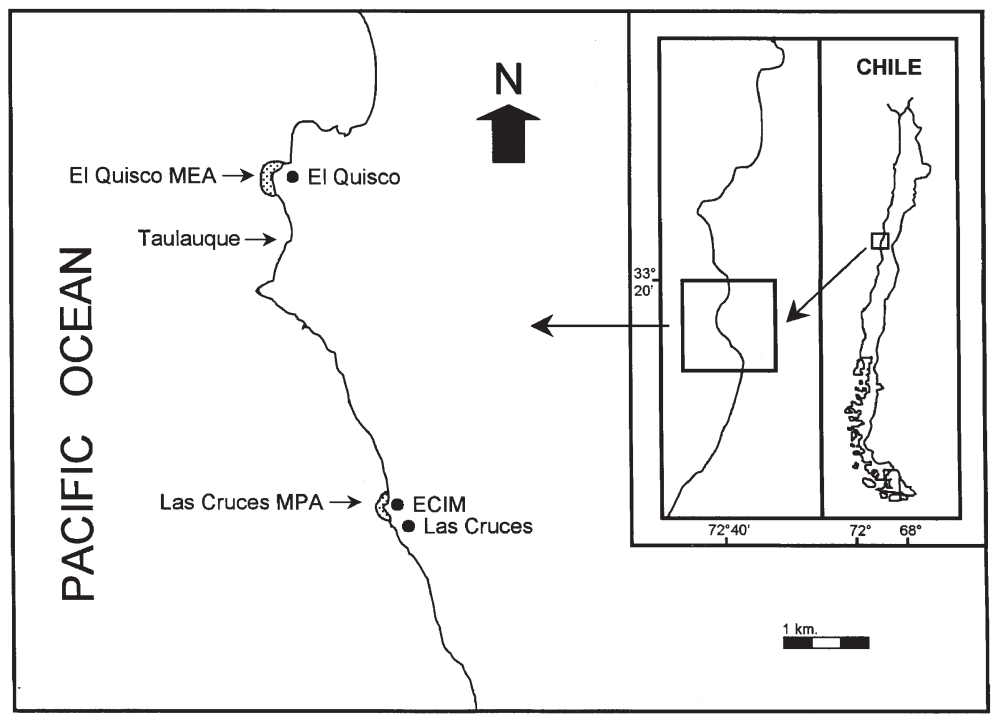

Fig. 1. Map showing study area where egg capsules and specimens of Concholepas concholepas were investigated in central Chile. ECIM: Estación Costera de Investigaciones Marinas; MEA: management and exploitation area; MPA: marine protected area
\& Castilla 1986). Five strip-transects (Eberhardt 1978), $100 \mathrm{~m}$ long $\times 2 \mathrm{~m}$ wide, and parallel to the shore line, were randomly selected at the beginning of the study and monitored monthly during low tides between September 1990 and December 1994 in each area. The transects were in the mid-low intertidal belt, at the Lessonia nigrescens level (Santelices et al. 1980, Castilla 1981, 1988b), and were identified with plastic markers fixed to rocks with epoxy resin. Within each area, Concholepas concholepas egg capsules (Castilla \& Cancino 1976) cemented (i.e. deposited by snails) to the rocks were monitored monthly. This included drawing maps and determining the surface occupied by newly deposited egg capsules. This was done simultaneously by 2 scientists along each transect. The egg capsules were classified to stage and condition according to color, as determined in previous field and laboratory observations: (1) full white-yellowish capsules were considered to have been deposited within the preceding 20 to $30 \mathrm{~d}_{i}(2)$ brownish capsules were considered to have been deposited in the preceding 30 to $40 \mathrm{~d}_{i}$ (3) pink capsules were classified as containing physically stressed or infected embryos (Spight 1977); (4) empty undamaged white capsules were considered as hatched. Capsules remain cemented to the substratum for about 3 mo during the egg development (Castilla \& Cancino 1976) and about 1 to 2 further months after the larvae hatch (Manríquez pers. obs.). The surface occupied by each group of capsules was estimated by tracing the borders onto transparent acetate sheets, which were later digitized in the laboratory with a digital planimeter (USHIKATA, Digi-Plan 220L). The number of capsules per unit surface was estimated from previous counts of the number of egg capsules found in groups of known surface area.

For egg capsules found cemented in narrow crevices, the surface area was estimated according to the closest geometrical figure measured with a caliper to the nearest $1 \mathrm{~mm}$. Groups of capsules deposited by an individual female always face in the same direction and are of approximately the same length (Castilla \& Cancino 1976). The length of capsules within a group was determined by measuring 1 detached capsule per group to the nearest $1 \mathrm{~mm}$. Sizefrequency distribution differences of capsules between the no-take, semi-protected and open-access fishery areas were tested with a Kolmogorov-Smirnov test. Annual production of larvae was calculated from measurements of area occupied by capsules and from capsule size. The area occupied by capsules was transformed into 
number of capsules and the number of capsules into number of larvae by using regressions of the relationships between (1) number of capsules per surface unit versus capsule length, and (2) number of larvae versus capsule length. The number of larvae per capsule was obtained from capsules collected from intertidal and subtidal areas and from the walls of storage tanks at the Estación Costera de Investigaciones Marinas (ECIM) at Las Cruces, by the methods described by Castilla \& Cancino (1976). Analyses of covariance (ANCOVA) were used to compare the regression lines between collection sites (i.e. intertidal, subtidal and laboratory conditions), relating the covariate and the response variables. Where we failed to reject the hypothesis of homogeneity of the slopes and the hypothesis of intercept equality, a single regression model was used to represent the data set for all $3 \mathrm{col}-$ lection sites combined. However, when the slopes were parallel and the intercepts significantly different from each other, an individual regression line for each collection site was used in the estimations of the response variables. All ANCOVAs were performed using a range of those covariates for which the response variables were represented at all 3 collection sites. When intercepts differed, a multiple comparison procedure based on adjusted means was used to test the differences among collection sites. To assure an overall protection level, only probabilities associated with preplanned comparisons were used (i.e. intertidal vs subtidal sites).

The population density and size (maximum peristomal length; Castilla 1974) of adults observed in each transect were evaluated at the peak of mass spawning (Castilla 1982) during the low tides of April 1991 and April 1993. Only specimens over $2 \mathrm{~cm}$ were counted; those larger than $5 \mathrm{~cm}$ were considered as reproductively mature (Herrera \& Alvial 1983, Durán \& Castilla 1988).

The subtidal study was carried out between January 1993 and September 1994 at the management and exploitation (MEA) area of Caleta El Quisco (332 $23^{\prime} \mathrm{S}$, $71^{\circ} 42^{\prime} \mathrm{W}$ ) (Fig. 1). Sampling by diving was attempted monthly, with emphasis on June and July, at the end of the spawning season (Castilla 1982). The El Quisco MEA has a subtidal area of approximately 54 ha. It was assigned by the government to the El Quisco fishermens' Union in 1993. By using this official figure, the El Quisco fishermens' Union was legally allowed to control fishing exploitation in this fishing ground. The contrasting adjacent study site, an open-access fishery ground, is at Taulauque $\left(33^{\circ} 25^{\prime} \mathrm{S}, 71^{\circ} 42^{\prime} \mathrm{W}\right)$, about 4 to $5 \mathrm{~km}$ south of the MEA. Taulauque, with approximately 15 ha of sea bottom, is constantly exposed to shellfish exploitation, and Concholepas concholepas are taken by divers during the open fishing period, as well as during the closed season, when poaching occurs (Castilla et al. 1998). The El Quisco MEA was divided into 5 zones of about 10 ha of sea bottom each. C. concholepas egg capsules were assessed by 1 diver (SCUBA) swimming along rocky strip-transects, $30 \mathrm{~m}$ long and $3 \mathrm{~m}$ wide $(\mathrm{n}=34)$, perpendicular to the shore line, and divided into 10 continuous quadrats of $3 \times$ $3 \mathrm{~m}$. A $3 \mathrm{~m}$ long aluminum rod was used by a second diver in charge of transect location, quadrat area determinations, and egg capsule measurements.

To determine the number of capsules spawned, censuses were conducted at the El Quisco MEA and at Taulauque in July 1993 and September 1994 (it was not possible to dive at other times). Censuses included enumeration of newly cemented (white), old unhatched (brownish) and empty capsules in the transects. To estimate the number of egg capsules cemented by individual Concholepas concholepas females during an entire spawning season, a series of observations was made in both the laboratory and field. Specimens were tagged with plastic numbers cemented to their shells. In the laboratory and in the field, females tend to remain on the same spot during a spawning event (Castilla \& Cancino 1976), and capsules laid by a female show the same orientation and are of approximately the same size (Castilla \& Cancino 1976, Ramorino 1979). These features were used to assess groups of capsules as deposited in a single spawning events and to measure the surface occupied by capsule groups. In the laboratory between 1991 and 1996, 30 specimens from the Las Cruces intertidal rocky shore, with a 1:1 sex ratio (Castilla 1974), were maintained at ECIM in a 1001 fiberglass rearing tank (flow-through seawater, temperature 13 to $16^{\circ} \mathrm{C}$, air continuously bubbled from an oil-free compressor), and fed ad libitum with living mussels (Perumytilus purpuratus). In the field, 20 females collected from the Las Cruces intertidal were measured, tagged, and returned to the collection site. Twice a month, between January and September 1991, the females were monitored during the lowest tides. If they were cementing egg capsules, the surface of the laying area and the size of 1 capsule in the group were measured by means of the mapping methodology described above. To avoid disturbing the laying process, females were not detached during the measurements.

\section{RESULTS}

Larger Concholepas concholepas females produced larger egg capsules (Fig. 2a). This tendency was independent of collection site (intertidal or subtidal) or laboratory conditions. The ANCOVA examining egg capsule length as a function of female length for each 

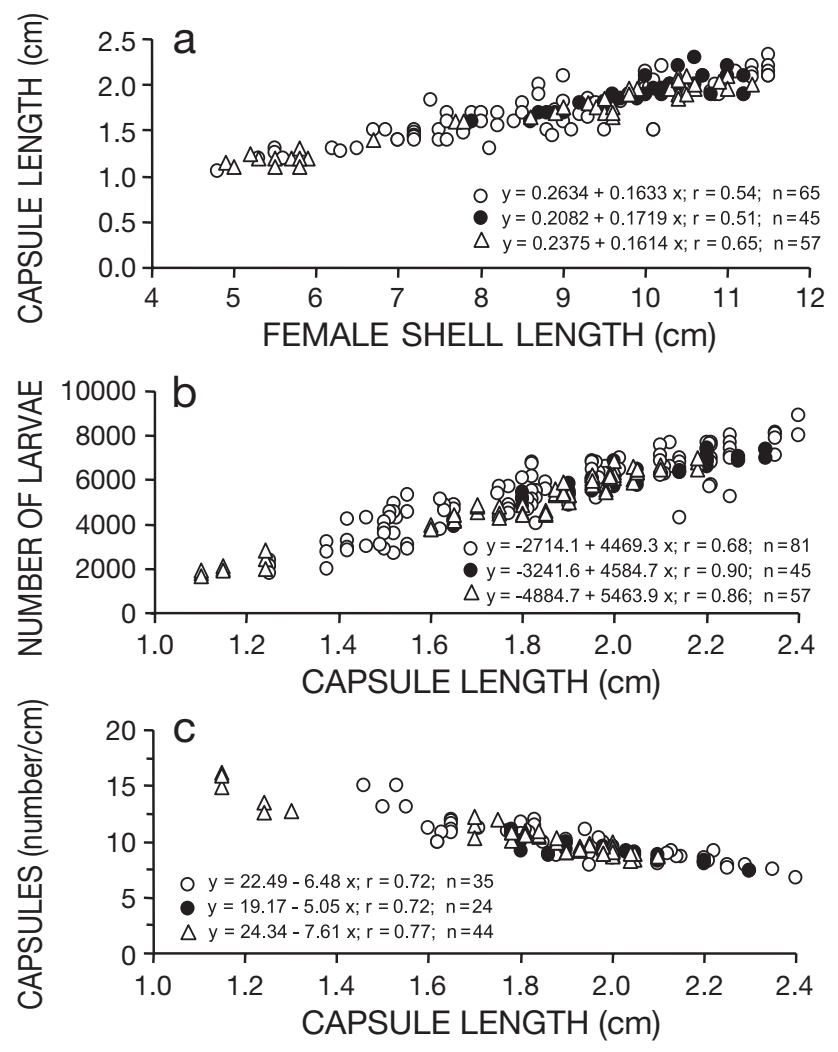

Fig. 2. Concholepas concholepas. (a) Relationship between female shell length and length of cemented egg capsules; (b) egg capsule length versus number of larvae contained; (c) capsule length versus number of egg capsules cemented per $\mathrm{cm}^{2}$ substrate. Data for egg capsules laid by females in intertidal $(0)$, subtidal $(\bullet)$ and laboratory $(\Delta)$. All regressions are significant at $\mathrm{p}<0.0001$

collection site shows homogeneous slopes $\left(F_{(2,119)}=\right.$ $0.13, \mathrm{p}>0.05)$; and intercepts that do not differ significantly $\left(F_{(2,121)}=0.90, \mathrm{p}>0.05\right)$. The number of larvae inside the capsules increased linearly with increasing length of the capsules (Fig. 2b). The ANCOVA ex- amining number of larvae as a function of capsule length for each collection site indicates homogeneity of slopes $\left(F_{(2,175)}=1.88, \mathrm{p}>0.05\right)$. However, intercepts were significantly different $\left(F_{(2,177)}=5.05, \mathrm{p}<0.05\right)$. A multiple comparison procedure indicated significant differences $(\mathrm{p}<0.05)$ between the intertidal and subtidal intercepts; therefore, 2 regressions were used to calculate the number of larvae produced by intertidal and subtidal transects (see Fig. 2b). The number of capsules cemented per $\mathrm{cm}^{2}$ decreased linearly with increasing of capsule size (Fig. 2c). The ANCOVA examining number of capsules cemented per $\mathrm{cm}^{2}$ as a function of capsule size for each collection site indicated homogeneity of slopes $\left(F_{(2,96)}=2.63, \mathrm{p}>0.05\right)$, and significant differences among the intercepts $\left(F_{(2,98)}=5.57, \mathrm{p}<0.05\right)$. A multiple comparison procedure detected significant differences among transects from the intertidal and subtidal $(\mathrm{p}<0.05)$; therefore, 2 regressions were used to calculate the number of capsules cemented per $\mathrm{cm}^{2}$ in intertidal and subtidal transects as a function of capsule size (see Fig. 2c).

\section{Intertidal area}

Groups of mating and spawning Concholepas concholepas tend to gather at or near the same sites each year. Capsules were deposited mainly on vertical surfaces and crevices and only in few cases on horizontal surfaces. Most of the capsule masses were located close to the water level during the lowest tides (i.e. around the kelp, Lessonia nigrescens, belt; Santelices et al. 1980, Castilla 1981, 1988b) (Fig. 3). The density and size distribution of individuals in the 3 intertidal areas varied. The average density in the open-access area was very low, $0.01 \mathrm{~m}^{-2}$; in the semi-protected area it lay between 0.11 and $0.16 \mathrm{~m}^{-2}$, and in the MPA between 0.94 and $0.99 \mathrm{~m}^{-2}$. These differences are greater when reproductively mature individuals, larger than $5 \mathrm{~cm}$,

Table 1. Concholepas concholepas. Mean density and mean length of peristome at the 3 intertidal areas studied. Specimens considered were those longer than $2 \mathrm{~cm}$ in the strip transect; longer than $5 \mathrm{~cm}$ were considered to be reproductive, n: no. of transects; MPA: marine protected area

\begin{tabular}{|c|c|c|c|c|c|}
\hline \multirow[t]{2}{*}{ Year and site: } & \multirow[t]{2}{*}{$\mathrm{n}$} & \multicolumn{2}{|c|}{ Total } & \multicolumn{2}{|c|}{ Reproductively mature } \\
\hline & & $\begin{array}{l}\text { Mean (SD) density } \\
\quad\left(\text { ind. } \mathrm{m}^{-2} \text { ) }\right.\end{array}$ & $\begin{array}{c}\text { Mean (SD) length } \\
(\mathrm{cm})\end{array}$ & $\begin{array}{l}\text { Mean (SD) density } \\
\quad\left(\text { ind. } \mathrm{m}^{-2} \text { ) }\right.\end{array}$ & $\begin{array}{c}\text { Mean (SD) length } \\
\text { (cm) }\end{array}$ \\
\hline \multicolumn{6}{|l|}{ April 1991: } \\
\hline No-take MPA & 5 & $0.94(0.39)$ & $6.42(2.49)$ & $0.64(0.37)$ & $7.82(1.80)$ \\
\hline Semi-protected & 7 & $0.16(0.08)$ & $3.91(1.06)$ & $0.03(0.01)$ & $5.52(0.51)$ \\
\hline Open-access & 5 & $0.01(0.01)$ & $3.14(0.05)$ & 0 & - \\
\hline \multicolumn{6}{|l|}{ April 1993: } \\
\hline No-take MPA & 5 & $0.99(0.15)$ & $6.59(2.47)$ & $0.72(0.14)$ & $7.91(1.80)$ \\
\hline Semi-protected & 7 & $0.11(0.02)$ & $4.53(1.15)$ & $0.03(0.01)$ & $5.86(0.52)$ \\
\hline Open-access & 5 & $0.01(0.01)$ & $3.13(0.60)$ & 0 & - \\
\hline
\end{tabular}




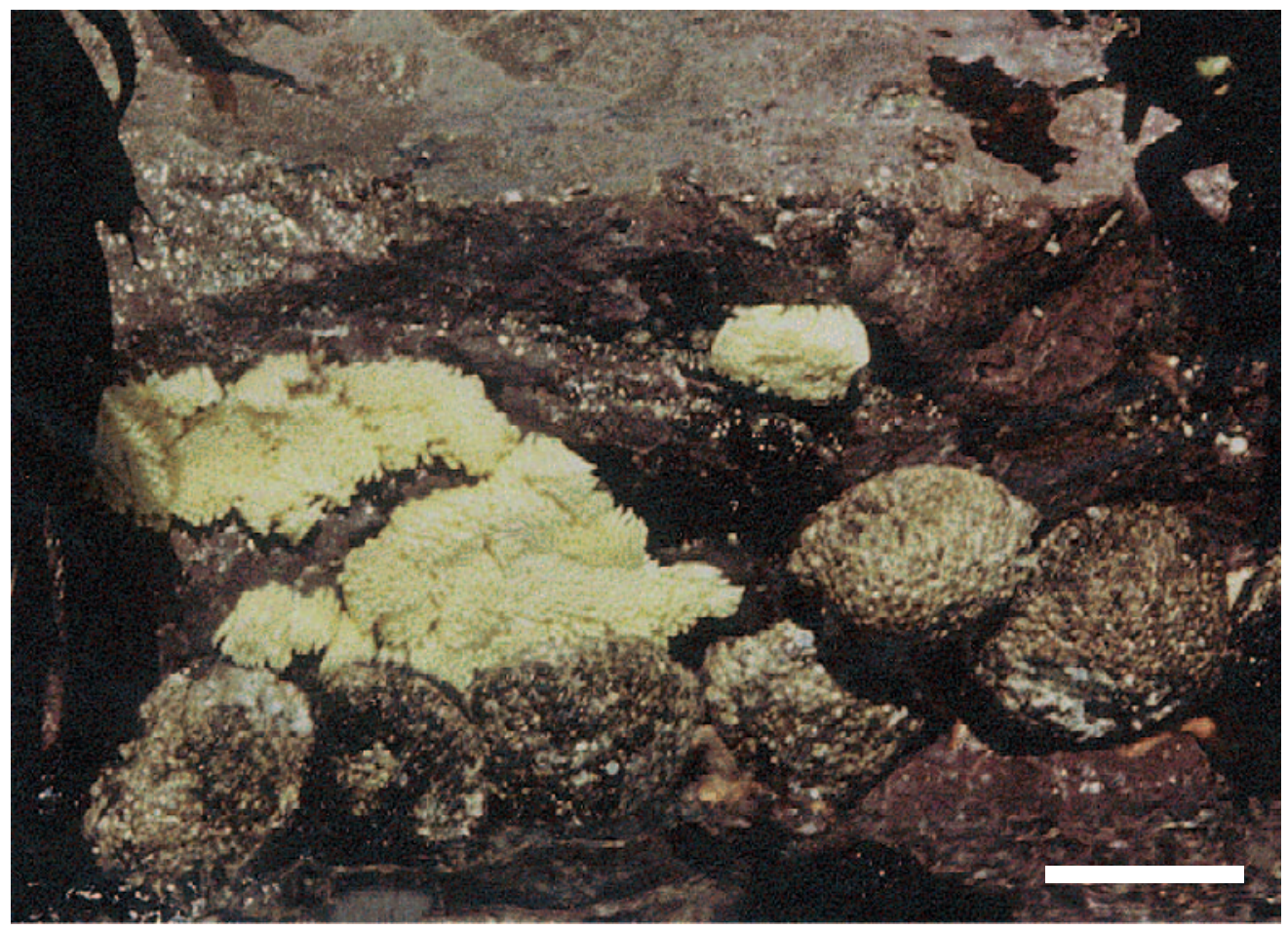

Fig. 3. Concholepas concholepas. General view of groups of gastropods and egg capsules during deposition period. On intertidal vertical wall below the kelp (Lessonia nigrescens) belt during lowest tides at Las Cruces MPA. (Scale bar $=10 \mathrm{~cm}$ )

are compared (Table 1). Mean density in the MPA transects was about 2 orders of magnitude higher than in the other 2 areas (Table 1). Correspondingly, in 1990 to 1993 , the mean size of the capsules $(1.67$ to $1.83 \mathrm{~cm})$ deposited in the MPA was significantly larger than in the semi-protected area (1.32 to $1.65 \mathrm{~cm}$; see Kolmogorov-Smirnov tests: Fig. 4). Capsule densities in the intertidal transects at the Las Cruces MPA and adjacent semi-protected area (and on 1 occasion at the adjacent open-access area) peaked around April/May, with a maximum mean of about $0.2 \mathrm{~m}^{2}$ capsule surfacecover per $1 \mathrm{~m}^{2}$ rock (Fig. 5). An increase in capsule density of up to 3 orders of magnitude was observed at the MPA (Fig. 5a) compared to the adjacent semi-protected and open-access areas (Fig. 5b,c).

Table 2 summarizes the estimated average number of Concholepas concholepas larvae hatching annually (1990 to 1993) from the capsules monitored at the Las
Cruces MPA and the adjacent semi-protected area (the 1990 data are based on a single sample made in September). The adjacent open-access area provides a dramatic contrast with practically no larvae hatching. In 1991, a $100 \mathrm{~m}^{2}$ transect in the MPA generated about 3 times as many larvae as an equivalent transect in the adjacent semi-protected area: $27.14 \times 10^{6}$ vs $8.93 \times 10^{6}$. In 1993, the difference increased by approximately 37 times: $290.50 \times 10^{6}$ vs $7.58 \times 10^{6}$ (Table 2 ).

In 1991, 8 tagged females, 8.9 to $10.8 \mathrm{~cm}$ in length, found in the MPA rocky intertidal, cemented a mean of 609 ( $\mathrm{SE}=26.21$ ) capsules per female, with an estimated mean number of hatched larvae of $3.36 \times 10^{6}$ ( $\mathrm{SE}=0.21$ ). In 1991 to 1995,25 tagged females, 7 to $11 \mathrm{~cm}$ in length, cemented in the laboratory an annual mean of 413.56 ( $\mathrm{SE}=32.28$ ) capsules per female, with an estimated mean number of hatched larvae of $2.27 \times$ $10^{6}(\mathrm{SE}=0.22)$.

Table 2. Concholepas concholepas. Estimated mean numbers (SD) in millions of larvae hatched per strip transect (100 $\left.\mathrm{m}^{2}\right)$ in the 3 intertidal areas studied. n: no. of transects

\begin{tabular}{|c|c|c|c|c|c|c|c|c|c|}
\hline \multirow{2}{*}{ Year } & \multicolumn{3}{|c|}{$\longrightarrow$ No-take MPA } & \multicolumn{3}{|c|}{ Semi-protected -} & \multirow[b]{2}{*}{$\mathrm{n}$} & \multicolumn{2}{|c|}{ Open-access } \\
\hline & $\mathrm{n}$ & $\begin{array}{l}\text { No. of capsules } \\
\text { per transect (SD) }\end{array}$ & $\begin{array}{c}\text { No. of larvae } \\
\text { per transect }\end{array}$ & $\mathrm{n}$ & $\begin{array}{l}\text { No. of capsules } \\
\text { per transect (SD) }\end{array}$ & $\begin{array}{l}\text { No. of larvae } \\
\text { per transect }\end{array}$ & & $\begin{array}{c}\text { No. of capsules } \\
\text { per transect }\end{array}$ & $\begin{array}{l}\text { No. of larvae } \\
\text { per transect }\end{array}$ \\
\hline 1990 & 5 & $2512(660)$ & $11.64(3.06)$ & 7 & $245(95)$ & $3.94(0.20)$ & 5 & 0 & 0 \\
\hline 1991 & 5 & $5703(1507)$ & $27.14(6.92)$ & 7 & $2775(1114)$ & $8.93(3.34)$ & 5 & 8 & 0.026 \\
\hline 1992 & 5 & $50910(17866)$ & $184.34(49.44)$ & 7 & $594(537)$ & $4.19(2.28)$ & 5 & 0 & 0 \\
\hline 1993 & 5 & $53487(8640)$ & $290.50(45.76)$ & 7 & $1371(355)$ & $7.58(1.42)$ & 5 & 0 & 0 \\
\hline
\end{tabular}



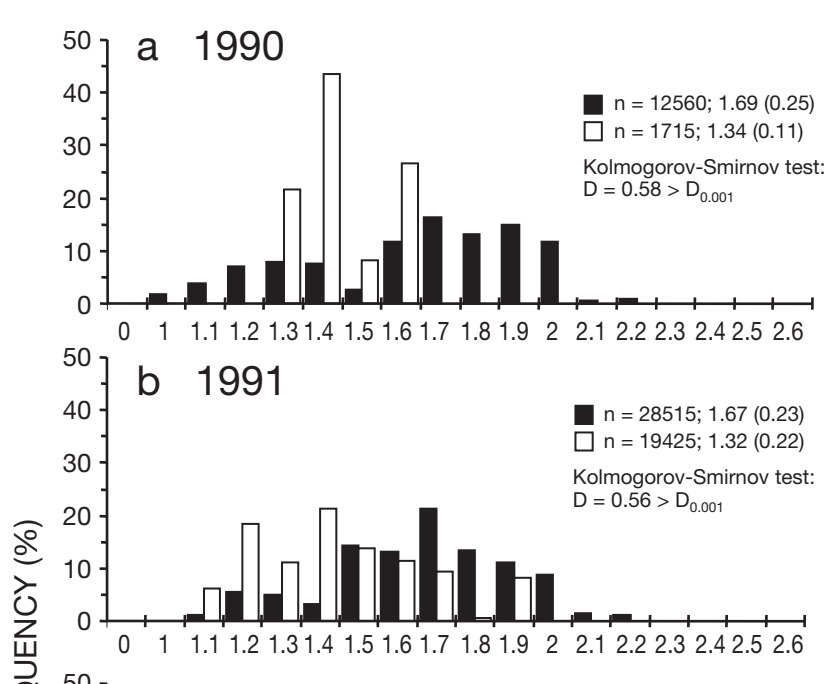
ơ ${ }^{50}$ ]. C 1992

崩
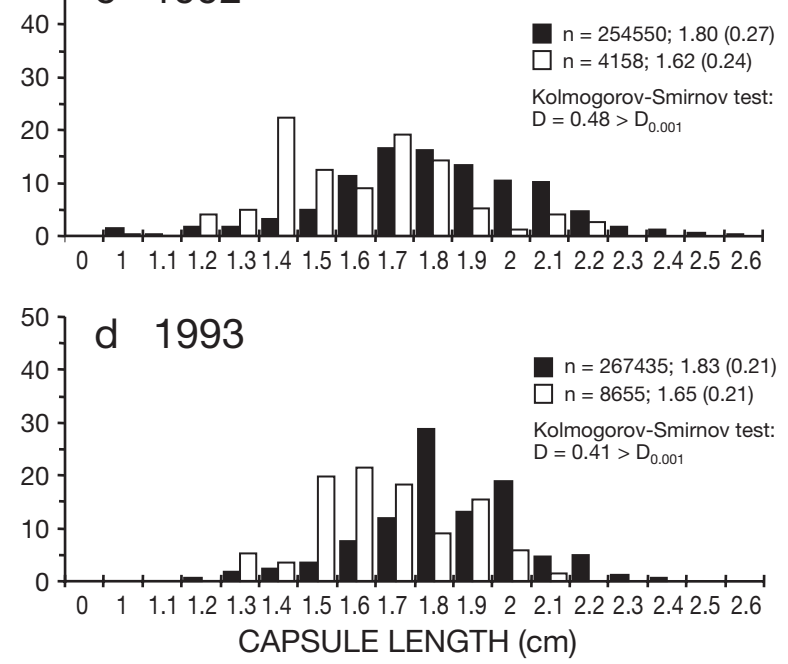

Fig. 4. Concholepas concholepas. Intertidal size structure of C. concholepas egg capsules (annual) at Las Cruces MPA (filled bars) and semi-protected area (open bars), 1990-1993. Results of Kolmogorov-Smirnov tests are shown

\section{Subtidal area}

Despite logistic diving problems at El Quisco MEA and Taulauque open-access areas, we determined the peak density of Concholepas concholepas capsule deposition. In the MEA (1993 and 1994), the peak mean density per $\mathrm{m}^{2}$ rock ranged between 0.12 and $0.19 \mathrm{~m}^{2}$ capsules, a density 3 to 4 times higher than in the open-access area (0.03 to $0.06 \mathrm{~m}^{2}$ capsules: Fig. 6$)$. The mean length of capsules in the MEA ranged between 1.91 and $2.01 \mathrm{~cm}$ and was significantly larger than in the open-access area (1.53 to $1.64 \mathrm{~cm}$, see Kolmogorow-Smirnov tests; Fig. 7). Table 3 summarizes the estimated mean numbers of $C$. concholepas larvae hatching annually from a $90 \mathrm{~m}^{2}$ transect in the MEA and in the open-access area. In 1993, a transect at the

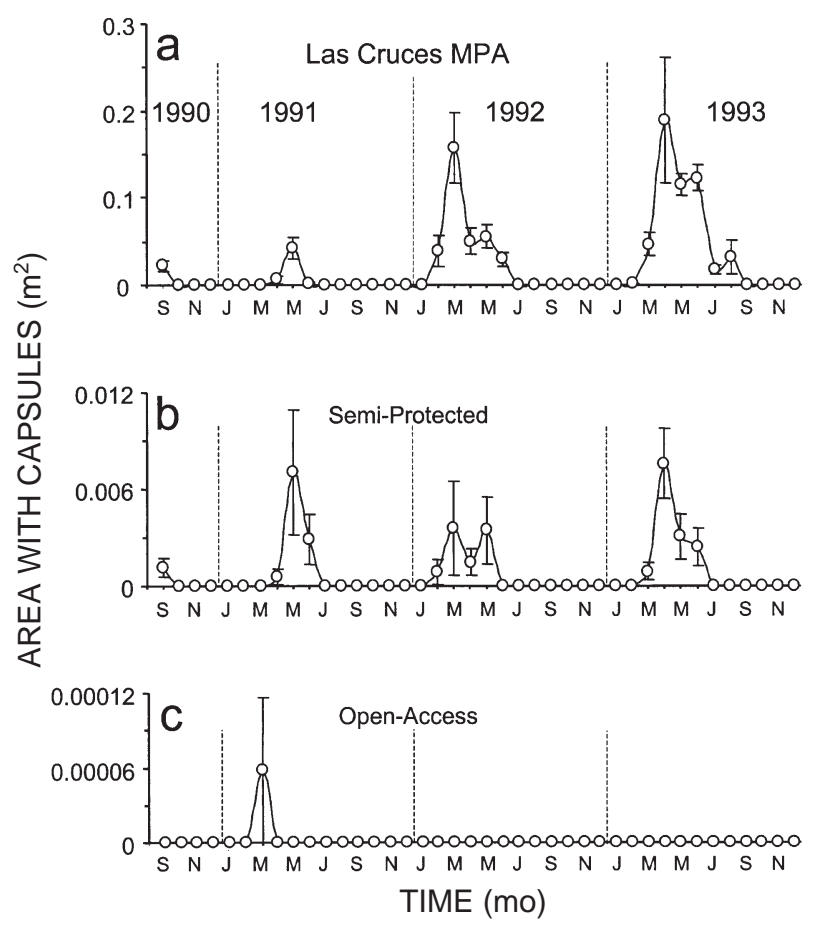

Fig. 5. Concholepas concholepas. Area $\left(\mathrm{m}^{2}\right)$ occupied by newly cemented egg capsules along intertidal strip transects. (a) Las Cruces MPA; (b) semi-protected area; (c) open-access fishing ground. Data are means $\pm \mathrm{SE}$

MEA produced a mean of $428.5 \times 10^{6}$ larvae, about 19 times more than in an open-access transect (Table 3). Similarly, in 1994, a transect in the MEA produced a mean about 16 times more than in an open-access transect (Table 3).

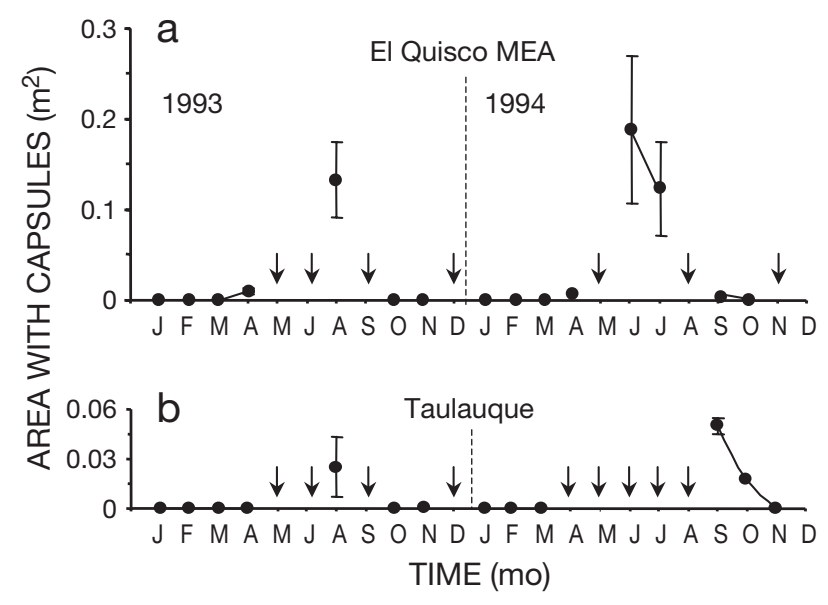

Fig. 6. Concholepas concholepas. Area $\left(\mathrm{m}^{2}\right)$ covered by newly cemented egg capsules along subtidal strip transects. (a) El Quisco MEA; (b) Taulauque, an open-access area. Arrows denote no sampling. Data are means $\pm \mathrm{SE}$ 
Table 3. Concholepas concholepas. Estimated mean numbers (SD) in millions of larvae hatched per strip transect $\left(90 \mathrm{~m}^{2}\right)$ in the 2 subtidal areas studied. MEA: management and exploitation area; n: no. of transects

\begin{tabular}{|c|c|c|c|c|c|c|}
\hline \multirow[t]{2}{*}{ Year } & \multirow{2}{*}{$\overline{\mathrm{n}}$} & \multicolumn{2}{|c|}{ El Quisco MEA } & \multicolumn{3}{|c|}{ _ Taulanque open-access } \\
\hline & & $\begin{array}{c}\text { Mean no. of capsules } \\
\text { per transect (SD) } \\
\text { (SD) }\end{array}$ & $\begin{array}{l}\text { Mean no of } \\
\text { larvae per transect } \\
\text { Million (SD) }\end{array}$ & $\mathrm{n}$ & $\begin{array}{c}\text { Mean no. of } \\
\text { capsules per transect } \\
\text { (SD) }\end{array}$ & $\begin{array}{l}\text { Mean no. of } \\
\text { larvae per transect } \\
\text { Million (SD) }\end{array}$ \\
\hline 1993 & 12 & $69232(5817)$ & $428.50(36.30)$ & 6 & $6677(2523)$ & $22.55(7.30)$ \\
\hline 1994 & 12 & $75996(5971)$ & $533.69(46.36)$ & 4 & $9933(2875)$ & $34.35(4.08)$ \\
\hline
\end{tabular}

\section{DISCUSSION}

Our results show the effects of a no-take area on production of Concholepas concholepas larvae. We suggest that the dramatic increase in production of larvae inside the no-take area reported in this study is the
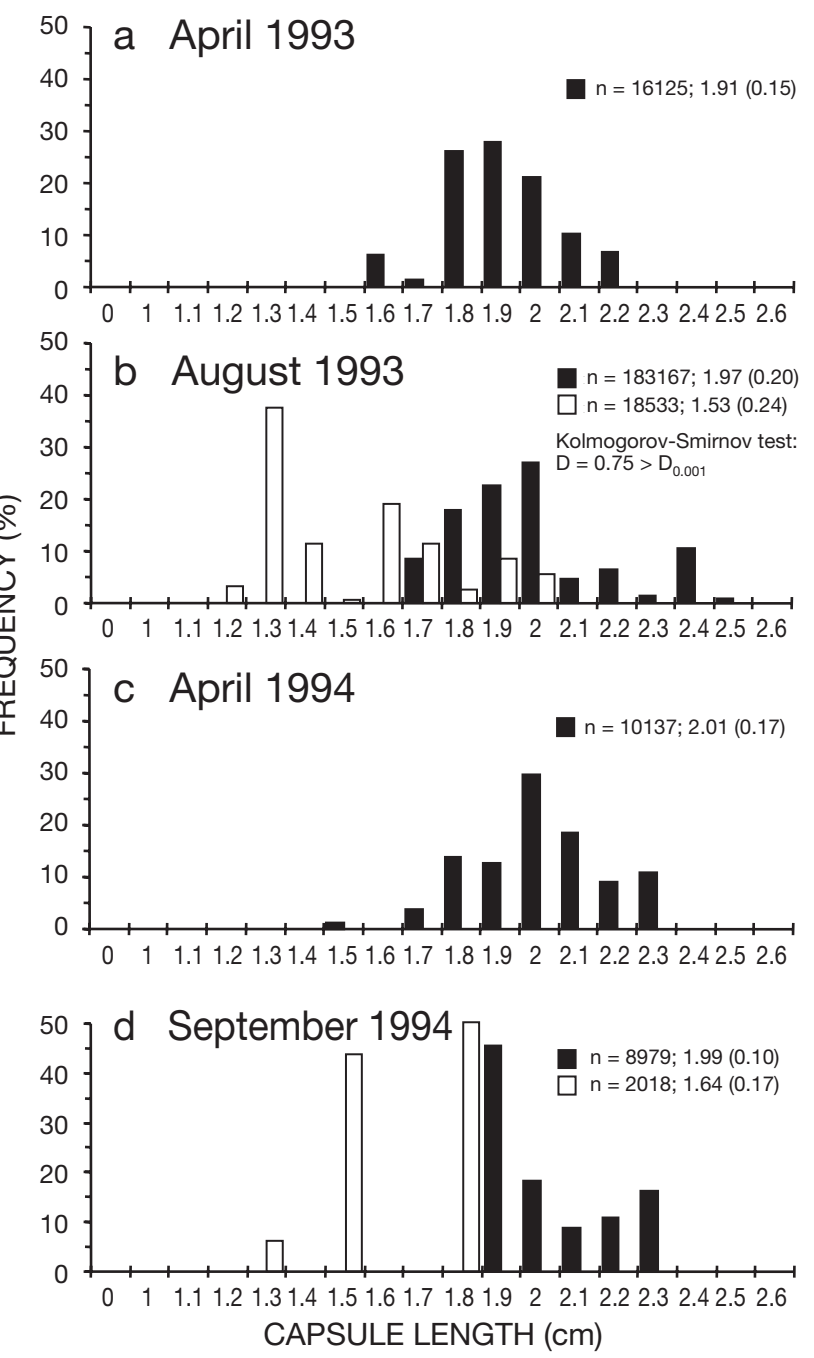

Fig. 7. Concholepas concholepas. Subtidal size structure of egg capsules (annual) at El Quisco MEA (filled bars) and open-access area (open bars), 1993-1994. Results of Kolmogorov-Smirnov tests are shown where distributions overlap results of the decline or absence of fishing activity. We have no explanation for the 1 order of magnitude difference between the number of larvae produced in 1991 and in 1992/1993 inside the no-take intertidal MPA or for the less marked differences observed in the semi-protected area. These may have been the result of differences in the abundance of the reproductive stock in the intertidal as a consequence of a failure in the population's annual migration from the subtidal (Castilla 1982, Castilla \& Durán 1985) and/or natural fluctuations in reproductive effort.

While the present study does not directly address habitat impact (i.e. intertidal or subtidal) on the reproductive contribution of Concholepas concholepas, the similarity between the maximal number of $C$. concholepas larvae produced annually by intertidal and subtidal transects suggests similar reproductive contributions per unit area. However, since the reproductive stock of C. concholepas mainly occupies subtital habitats (Castilla 1982), it is expected that, as a whole, the subtidal reproductive contribution is greater than the intertidal contribution.

Our observations agree with previous work (Castilla \& Cancino 1976, Durán \& Castilla 1988) showing that larger Concholepas concholepas spawn larger capsules. However, unlike previous papers, our observations also included individuals in the field. As in early studies, deposition of egg capsules was associated with specimens larger than 4 to $5 \mathrm{~cm}$. This agrees with the prediction for muricid gastropods made by Spight et al. (1974) that reproduction is delayed until a snail reaches a size at which it is capable of investing its entire annual net energy intake in eggs.

Our field and laboratory observations indicate that Concholepas concholepas larval production ranges from about 4 to 8 million per female during a spawning season. These numbers are similar to data from laboratory investigations by Durán \& Castilla (1988). The high densities and large body length of C. concholepas associated with the no-take area at Las Cruces are in agreement with previous studies (Castilla \& Durán 1985, Oliva \& Castilla 1990). Our results suggest that spawning aggregations are concentrated between April and June in both the intertidal and subtidal 
habitats. This suggests synchronous spawning, and is also in agreement with previous work (Castilla 1974, Castilla \& Schmiede 1979, Durán \& Castilla 1988). Spight (1977) suggested that patterns of spawning in intertidal muricid snails would be a compromise of the needs of different stages in their life history. Most intertidal aggregations and egg capsules of C. concholepas are located on vertical surfaces. Our observations suggest that females tend to lay egg capsules in the low intertidal, where exposures are less frequent and brief, and mainly on vertical surfaces and crevices, i.e. in optimal places for spawning and development. In the laboratory, we found that developmental success of C. concholepas larvae in the egg capsules is linked to their orientation (i.e. vertical or horizontal), desiccation, and temperature. Furthermore, the laboratory study indicated that deformations or absence of the larval shell are associated with horizontal, upwardfacing surfaces. This illustrates the adaptive benefit of egg capsule deposition on vertical surfaces in maximizing development success, and is supported by our field observations of the presence of more egg capsules on these surfaces.

The existence of a long larval dispersal phase (several months) in Concholepas concholepas (Gallardo 1979, Ramorino 1979, DiSalvo 1988) may allow adults reproducing within a no-take area to contribute to fishing grounds well outside the reserves. Because fishery mortality is very low to zero in the MPAs, and is controlled in the MEAs (Castilla et al. 1998), both the density and the longevity of the contained organisms are increased. Thus, since egg capsule-production scales linearly with the number of females and with body size, more and larger egg capsules are produced each spawning season within the no-take area than in open fishing grounds. On exposed shores, most planktonic larvae of benthic organisms are unlikely to remain in the same place as their parents (Roughgarden et al. 1988, Underwood \& Fairweather 1989). For feeding larvae of types for which there is no obvious physiological limit for settlement, time for growth to competence represents the minimum time to settlement. Similarly, a theoretical relationship between the duration of the competent-precompetent phase and energetics has been proposed by Jackson \& Strathmann (1981). A longer precompetent period should be balanced by a longer competent period to allow larvae to return to asuitable adult habitat. In C. concholepas, the precompetent period inferred from laboratory rearing of larvae is about 3 mo (DiSalvo 1988); however, the duration of the competent period is largely unknown. Our own unpublished experiments on competent $C$. concholepas larvae collected from the surface plankton suggest that they can successfully delay metamorphosis for up to 2 mo in the absence of poten- tial inducers in the rearing vessels (i.e. presence of prey or conspecific juveniles in the habitats where larvae recruit). However, a full estimation of the competent period and the capacity for delaying metamorphosis in competent C. concholepas larvae would require information on their spatial distribution. Competent C. concholepas larvae caught in the surface plankton could correspond to late larval stages close to the shift from competent form to settling and successful metamorphosis. Consequently, the competent period may be longer than would be inferred from larvae caught in the surface plankton.

Little information is available on larval dispersal in Concholepas concholepas; however, high concentrations of competent $C$. concholepas larvae (i.e. capable of settling) have been reported in nearshore surface plankton (DiSalvo 1988, and authors' unpubl. data). Our own unpublished laboratory observations suggest that the surface-seeking behavior of competent C. concholepas larvae could be coupled with their capacity to cling to pieces of substratum floating at the water surface. Our field observations also suggest that larval transport in $C$. concholepas may be augmented by floating or rafting. Previous studies have demonstrated that competent $C$. concholepas larvae can produce a mucous byssal thread that they can use for flotation, as the thread adheres to the water surface (DiSalvo 1988). These observations have been corroborated by our observations in the laboratory; however, our laboratory observations also suggest that the mucous thread can be used by competent larvae to adhere to substratum floating on the water surface (Manríquez \& Castilla unpubl.). Moreover, if larvae feed during the competent period, this stage could exceed the precompetent period, delaying metamorphosis until the larvae are passively transported to inshore shallow water. This suggests that dispersal from no-take or seeding areas could be greater than would be expected from energetic considerations alone.

The spatial scale of the effective seeding process in neighboring areas depends not only on larval behavior. Vertical dispersal or migration can also be affected by oceanographic processes such as internal waves, internal tidal bores and fronts (Shanks 1985, 1995, Shanks \& Wright 1987). The effects of coastal circulation on larval dispersal, the spatial distribution of invertebrate recruitment, and their implications for management (i.e. spacing and size of no-take areas) have been considered in the literature (e.g. Wing et al. 1998). Full appreciation of larval dispersal from notake areas will require the integration of larval biology and coastal oceanography to estimate both the potential and direction of dispersal distances.

Our quantitative evaluation of MPAs and MEAs as seeding areas confirms the importance of non-har- 
vested or harvest-controlled areas to nearshore resources. The potential benefit of protective management to spawning stocks and the provision of recruits to replenish fishing grounds has been shown in this field study. The idea that no-take marine reserves can serve as 'sources' of larvae to support 'sink' populations elsewhere has been proposed in the literature (Roberts 1998, Castilla 2000). Although increases in adult densities imply greater larval export from notake MPAs and MEAs, there is still no direct confirmation of this. Among methods for labeling and tracking marine invertebrate larvae (reviewed by Levin 1990), genetic markers are the most promising. Genetic differences between populations of marine organisms revealed by mtDNA analysis have been proposed as an indirect estimator of larval dispersal (reviewed by Palumbi 1995). Genetic tools could make it possible to identify the 'source' of larvae or recruits, demonstrate larval mixing during dispersal, and determine the scale on which dispersal from the 'source' populations takes place. However, genetic marking is only possible if genetic differentiation exists among potential source populations. To date little is known about genetic differentiation in natural populations of Concholepas concholepas. Guiñez et al. (1992) suggested the presence of at least 2 genetic units in C. concholepas and the absence of 1 panmictic population. Despite the fact that gastropods display a notorious interspecific plasticity in shell morphology (Palmer 1985), our own observations on both shell morphology and ornamentation among natural populations of $C$. concholepas suggest the existence of geographically-differentiated subpopulations. Thus, these differences could correspond to genetically different stocks. However, contrary to Guiñez et al.'s (1992) results and to our observations, Gallardo \& Carrasco (1996) reported reduced levels of demit subdivision in a natural population of C. concholepas. Based on genetic substructuring measured by standardized variance in allele frequency, these authors concluded that genetic cohesiveness and high levels of gene flow among populations of C. concholepas are achieved by larval interchange. Unfortunately, due to the limited number of Chilean MPAs and MEAs and consequent lack of replication (but see Lagos \& Castilla 1997), the potential of tagging DNA-based techniques cannot be explored because of the mixing of larvae from outside non-harvested and harvestcontrolled source areas and the expressive amount of work involved in finding marked larvae in plankton samples. Moreover, spatial variation in shell morphology could also reflect phenotypic plasticity associated with predators, hydrodynamics stress and other environmental cues (e.g. Palmer 1980, 1985, 1990, Trussell 1997a,b).
We suggest that the concept of MPAs and MEAs as natural re-stocking areas (Castilla 1988c, 1999, Bustamante \& Castilla 1990, Oliva \& Castilla 1990) and the existence of 'buffer zones' along the Chilean coast (Castilla \& Schmiede 1979) or 'source' areas (Roberts 1998) may be implemented as a coastal marineresource management strategy (Castilla 2000). The presence of seasonal spawning aggregations, as in the case of Concholepas concholepas, suggests that this factor should be taken into account when designing no-take areas. Therefore, in order to assure reproductive output, fishing in marine protected areas (MPAs or MEAs) should be prohibited or regulated during the spawning seasons. From the data given herein, we conclude that the increases in density and body size of reproductive individuals that occur in no-take or harvest-controlled areas have important consequences in maximizing the reproductive capacity of a natural population. Thus, rather than being only a tool to preserve areas for scientific interest or enhance local benthic fisheries, MPAs and MEAs should be considered as sources of larval export to exploited areas. No-take areas have also proved to be an important source of juveniles and adults (Davis 1989, Attwood \& Bennett 1994), an important additional benefit of these areas.

Whether protection of a spawning stock, leading to increased larval production, can effectively lead to replenishment of nearby fishing grounds is a question that should be addressed through genetic, nearshore oceanographic and larval behavior studies. Information about the spatial impact or effectiveness of nonharvested areas will make it possible to establish more effective management strategies (e.g. Roberts \& Polunin 1991, Carr \& Reed 1993, Attwood et al. 1997, Allison et al. 1998, Castilla \& Fernández 1998). Information on the spatial distribution, size, and number of the take, no-take and harvest-controlled areas will also be essential for the establishment of networks of interdependent MPAs and the balanced exploitation of benthic resources (Castilla 2000).

Ackowledgements. The authors thank Armando Rosson, Sergio Vera, and Claudio Ramirez for help during the egg capsule sampling. We also acknowledge the collaboration of fishers from Caleta El Quisco for authorization to work inside their MEA. This work was supported by FONDECYT (Project 1930684), the 1997 Cátedra Presidencial granted to J.C.C., and the A. Mellon Foundation. Special thanks to Richard and Megumi Strathmann for providing helpful comments that improved this manuscript.

\section{LITERATURED CITED}

Allison GW, Lubchenco J, Carr MH (1988) Marine reserves are necessary but not sufficient for marine conservation. Ecol Appl (Suppl) 8:79-92 
Attwood CG, Bennett BA (1994) Variations in dispersal of galjoen (Coracinus capensis) (Teleostei: Coracinidae) from a marine reserve. Can J Fish Aquat Sci 51:1247-1257

Attwood GC, Harris JM, Williams AJ (1997) International experience of marine protected areas and their relevance to South Africa. S Afr J Mar Sci 18:311-332

Bohnsack JA (1993) Marine reserves: they enhance fisheries, reduce conflicts, and protect resources. Oceanus Fall 1993:63-71

Bustamante R, Castilla JC (1990) Impact of human exploitation on populations of the intertidal bull-kelp Durvillaea antartica (Phaeophyta, Durvilleales) in Central Chile. Biol Conserv 52:205-220

Carr MH, Reed DC (1993) Conceptual issues relevant to marine harvest refuges: examples from temperate reef fishes. Can J Fish Aquat Sci 50:2019-2028

Castilla JC (1974) Notes on mating behaviour of Concholepas concholepas (Mollusca, Gastropoda, Muricidae) from Chile. Veliger 16:291-292

Castilla JC (1981) Perspectivas de investigación en estructura y dinámica de comunidades intermareales rocosas de Chile central. II. Depredadores de alto nivel trófico. Medio Ambiente 5:190-215

Castilla JC (1982) Pesquería de moluscos gastrópodos en Chile: Concholepas concholepas, un caso de estudio. In: Castilla JC (ed) Segundo seminario taller: bases biológicas para el uso y manejo de recursos naturales renovables: recursos biológicos marinos. Pontificia Universidad Católica de Chile, Santiago, Chile. (Monogr Biol Nr 2), p 199-212

Castilla JC (1988a) Una revisión bibliográfica (1980-1988) sobre Concholepas concholepas (Gastropoda, Muricidae): problemas pesqueros y experiencias de repoblación. Biol Pesq 17:9-19

Castilla JC (1988b) Earthquake caused coastal uplift and its effects on rocky intertidal kelp communities. Science 424 : 440-443

Castilla JC (1988c) La problemática de la repoblación de mariscos en Chile: diagnósticos, estrategias y ejemplos. Investig Pesq (Chile) 35:41-48

Castilla JC (1994) The Chilean small-scale benthic shellfisheries and the institutionalization of new management practices. Ecol Int Bull 21:391-399

Castilla JC (1999) Coastal marine communities: trends and perspectives from human-exclusion experiments. Trends Ecol Evol 14:280-283

Castilla JC (2000) Roles of experimental marine ecology in coastal management and conservation. J Exp Mar Biol Ecol 250:3-21

Castilla JC, Cancino J (1976) Spawning behaviour and egg capsules of Concholepas concholepas (Mollusca: Gastropoda: Muricidae). Mar Biol 37:255-263

Castilla JC, Durán LR (1985) Human exclusion from the rocky intertidal zone of Central Chile. The effects of Concholepas concholepas (Mollusca: Gastropoda: Muricidae). Oikos 45:391-399

Castilla JC, Fernández M (1998) Small-scale benthic fisheries in Chile: on co-management and sustainable use of benthic invertebrates. Ecol Appl 8:124-132

Castilla JC, Schmiede P (1979) Hipótesis de trabajo sobre la existencia de zonas marítimas tampones en relación a recursos marinos bentónicos (mariscos y algas) en la costa de Chile continental. In: Gallardo VA (ed) Seminario taller sobre desarrollo e investigación de los recursos marinos de la Octava Región, Chile. Universidad de Concepción, Enero 9-13. 1978. Vicerrectoría de Investigación de la Universidad de Concepción, Chile, p 145-167
Castilla JC, Manríquez P, Alvarado J, Rosson A, Espoz C, Soto R, Defeo O (1998) Artisanal 'Caletas' as units of production and co-managers of benthic invertebrates in Chile. In: Jamieson GS, Campbell A (eds) Can Spec Publ Fish Aquat Sci 125:407-414

Davis GE (1989) Designated harvest refugia: the next stage of marine fishery management in California. CALCOFI (Calif Coop ocean Fish Ivestig) Rep 30:5-58

Durán R, Castilla JC (1988) Determinación de la fecundidad de Concholepas concholepas (Bruguière, 1789) (Gastropoda, Muricidae) en condiciones de laboratorio. Biol Pesq $17: 39-45$

DiSalvo LH (1988) Observations on the larval and post-metamorphic life of de Concholepas concholepas (Bruguière, 1789) in laboratory culture. Veliger 30:358-368

Eberhardt LL (1978) Transects methods for population studies. J Wildl Manag 42:1-31

Fernández M, Castilla JC (1997) The Chilean artisonal stone crab (Homalarpis plana) fishery: catch trends in open access zones and the effects of management areas in Central Chile. J Shellfish Res 16:371-377

Gallardo CS (1979) El ciclo vital del Muricidae Concholepas concholepas y consideraciones sobre sus primeras fases de vida en el bentos. Biol Pesq 12:79-89

Gallardo MH, Carrasco JI (1996) Genetic cohesiveness among population of Concholepas concholepas (Gastropoda, Muricidae) in Southern Chile. J Exp Mar Biol Ecol 197:237-249

Guiñez R, Gómez MV, Castilla JC (1992) Diferencia genética poblacional en Concholepas concholepas (Bruguière, 1789) (Gastropoda, Muricidae) en su área de distribución Centro-Norte. Biol Pesq 21:31-41

Herrera G, Alvial A (1983) Talla mínima de madurez gonádica en poblaciones de Concholepas concholepas (Bruguière, 1789, Mollusca: Gastropoda: Muricidae) en Iquique, Chile. Mem Asoc Latinoam Acuicult 5:289-293

Jackson GA, Strathmann RR (1981) Larval mortality from offshore mixing as a link between precompetent and competent periods of development. Am Nat 118:16-26

Lagos NA, Castilla JC (1997) Inferencia estadistica bayesiana en ecologia: un ejemplo del uso en una reserva marina chilena. Rev Chil Hist Nat 70:565-575

Levin LA (1990) A review of methods for labeling and tracking marine invertebrate larvae. Ophelia 32:115-144

Oliva D, Castilla JC (1986) The effects of human exclusion on the population structure of keyhole limpets Fissurella crassa and F. limbata on the coast of Central Chile. PSZN I Mar Ecol 7:201-207

Oliva D, Castilla JC (1990) Repoblación natural: el caso del loco Concholepas concholepas (Gastrópoda: Muricidae), en Chile Central. In: Hernández AH (ed) Cultivo de moluscos en América Latina. Memorias segunda reunión grupo de trabajo técnico. Noviembre 7-11; Red Regional de Enticades y Centros de Acuicultura de América Latina CIID-Canada, Bogotá, p 273-295

Palmer RA (1980) Locomotion rates and shell form in the Gastropoda: a re-evaluation. Malacologia 19:289-296

Palmer RA (1985) Quantum changes in gastropod shell morphology need not reflect speciation. Evolution 39:699-705

Palmer RA (1990) Effects of crab effluent and scent of damaged conspecifics on feeding, growth, and shell morphology of the Atlantic dogwhelk Nucella lapillus (L.). Hydrobiologia 193:155-182

Palumbi SR (1995) Using genetics as an indirect estimator of larval dispersal. In: McEdward L (ed) Ecology of marine invertebrate larvae. CRC Press, Inc, Boca Raton, FL, p 369-387 
Ramorino L (1979) Conocimiento científico actual sobre reproducción y desarrollo de Concholepas concholepas (Mollusca: Gastropoda: Muricidae). Biol Pesq 12:59-70

Roberts CM (1998) Source, sinks, and the design of marine reserve network. Fisheries (Bethesda) 23:16-19

Roberts CM, Polunin NVC (1991) Are marine reserves effective in management of reef fisheries? Rev Fish Biol Fish 1:65-91

Roughgarden J, Gaines S, Possingham H (1988) Recruits dynamics in complex life-cycles. Science 241:1460-1466

Santelices B, Castilla JC, Cancino J, Schmiede P (1980) Comparative ecology of Lessonia nigrescens and Durvillaea antarctica (Phaeophyta) in central Chile. Mar Biol 59: 119-132

Shanks AL (1985) Behavioral basis of internal-wave-induced shoreward transport of megalopae of crab Pachygrapsus crassipes. Mar Ecol Prog Ser 24:289-295

Shanks AL (1995) Mechanisms of cross-shelf dispersal of larval invertebrates and fish. In: McEdward L (ed) Ecology of marine invertebrate larvae. CRC Press, Inc, Boca Raton, FL, p 323-367

Editorial responsibility: Charles Peterson, Morehead City, North Carolina, USA
Shanks AL, Wright WG (1987) Internal-wave-mediated shoreward transport of cyprids, megalopae, and gammarids and correlated longshore differences in the settling rate of intertidal barnacles J Exp Mar Biol Ecol 114:1-13

Spight TM (1977) Do intertidal snail spawn in the right places? Evolution 31:682-691

Spight TM, Birkeland C, Lyons A (1974) Life histories of large and small murexes (Prosobranchia: Muricidae). Mar Biol 24:229-242

Trussell GC (1997a) Phenotypic plasticity in the foot size of an intertidal snail. Ecology 78:1033-1048

Trussell GC (1997b) Phenotypic selection in a intertidal snail: effects of a catastrophic storm. Mar Ecol Prog Ser 151: $73-79$

Underwood AJ, Fairweather PG (1989) Supply-side ecology and benthic marine assemblages. Trends Ecol Evol 4: $16-20$

Wing SR, Botsford LW, Quinn JF (1998) The importance of coastal circulation on the spatial distribution of invertebrates, with implications for management. Can Spec Publ Fish Aquat Sci 125:285-294

Submitted: May 5, 2000; Accepted: October 23, 2000

Proofs received from author(s): May 30, 2001 